\title{
A Sámi media system?
}

\author{
Torkel Rasmussen, ${ }^{\mathrm{I}}$ Inker-Anni Sara, ${ }^{\mathrm{I}} \&$ Roy Krøvel ${ }^{\mathrm{II}}$ \\ I Department of Sámi Teacher Education and Indigenous Journalism, Sámi University of Applied \\ Sciences, Norway \\ II Department of Journalism and Media Studies, Oslo Metropolitan University, Norway
}

\begin{abstract}
In this article, we propose a history of Sámi journalism and news media as a step in the direction of analysing the existing media system in Sápmi. Numerous Sámi activists and organisations have contributed to the establishment and running of Sámi media - in interaction, cooperation, and conflict with external actors such as missionaries, investors, and state institutions. This has resulted in a rich and vivid Sámi media environment and infrastructure, with many of the characteristics of a media system. However, fundamental processes governing the Sámi media system are subjected to regulations, procedures, and institutions external to Sámi society. This article calls for greater Sámi self-determination over key elements of the media system.
\end{abstract}

Keywords: indigenous and Sámi media systems, Sámi media history, Sámi self-determination, democratic corporatist model

\section{Introduction}

In this article, we analyse existing literature on Sámi media history to explore the question of autonomy in the Sámi media system. We do this exploration because it is difficult to imagine a fulfilment of Sámi self-determination in the future without a rich, diverse, and autonomous Sámi media. We explore the development of Sámi media and the possibility of a Sámi media system emerging from the specific Sámi historical context.

There are altogether around 100,000 Sámi: 50,000-75,000 in Norway, 25,000 in Sweden, 10,000 in Finland, and 2,000 in Russia. The Sámi are an indigenous people who speak ten different languages, of which the North Sámi language is the most widely spoken. The first Sámi Affairs Committees to address measures necessary to protect Sámi languages, culture, industries, and communities were established in 1947 in Norway, in 1949 in Finland, and in 1973 in Sweden. A Sámi movement - the establishment of Sámi organisations and an awareness of a distinct ethnic identity - started in the early 1900 s and grew in strength in the 1960s and 1970s (Kulonen et al., 2005). In 1956, the Sámi founded a common Nordic Sámi organisation, the Sámi Council (Kulonen et al., 2005). Later, the Sámi parliaments were founded in Norway (1989), Sweden (1993),

Rasmussen, T., Sara, I.-A., \& Krøvel, R. (2021). A Sámi media system? Nordicom Review, 42(S2), 22-35. https://doi.org/10.2478/nor-2021-0015 
and Finland (1995) (Lehtola, 2005) and continue to have limited autonomy over policies affecting Sámi societies (Broderstad, 2010).

Over the last few decades, the body of literature on indigenous media has expanded rapidly (Alia, 2012; Burrows, 2018; Hanusch, 2013, 2014; Ijäs, 2011, 2012; Markelin, 2003, 2017; McCallum \& Waller, 2017; Meadows, 2009; Skogerbø et al., 2018). However, little has been published on indigenous media systems, although important contributions deal with features of media "landscapes", "environments", or "infrastructures".

We contribute to an understanding of a Sámi media system by providing a historical synthesis based on existing research, mainly dealing with newspapers, radio, and television and engaging primarily with early media systems literature. We limit the scope of our synthesis to Sámi media in Norway, Sweden, and Finland, as Sámi media in Russia are few, have been in the interest of few studies (Rießler 2015), and are established in a different media system than other Sámi media, which are placed in the Nordic bloc of the democratic corporatist model of media systems (Hallin \& Mancini, 2004).

\section{Comparing Media Systems}

Hallin and Mancini (2004) introduced "three media system models": the liberal, the democratic corporatist, and the polarised pluralist models. The liberal model, located in the UK, Ireland, and North America, is dominated by "market mechanisms and commercial media" (Hallin \& Mancini, 2004: 11). The model of northern Europe, the democratic corporatist model, is a combination of the commercial media, the political press, and a relatively strong but regulated state interference. The polarised pluralist model in the Mediterranean area is known for strong party affiliation, strong state interference, and lacking commercial media features.

The democratic corporatist media system model seeks to identify links between political systems and media systems, where the former affects the ways in which the latter develops (Moe \& Sjøvaag, 2008). The different political, legal, and economic systems in the Nordic countries have shaped the media environments differently in each country (Markelin \& Husband, 2013). According to Markelin (2003: 258), the Sámi Parliament of Sweden has "stalled policy" and scarce resources when it comes to the institutional framework for the Sámi public service broadcasters. Nevertheless, Markelin (2003) notes that the Swedish government and administration have shown an emerging awareness of Sámi issues over the last decades and the Norwegian government has had a broad understanding of Sámi issues, while the Finnish government's awareness of Sámi issues has been more limited. The result is that more resources will be available to the Norwegian Sámi Parliament, facilitating more consistent policymaking, while coherent policy-making has been missing in the case of the Finnish Sámi Parliament (Markelin, 2003).

Many have questioned the appropriateness of applying Hallin and Mancini's media systems theory beyond the Western world. Hallin and Mancini (2012) themselves note that their 2004 text Comparing Media Systems: Three Models of Media and Politics, as theory building, was based on certain media systems sharing similar historical backgrounds, and therefore its temporal and local application is relatively limited.

Here, we investigate the media system in Sápmi (including northern regions of Norway, Finland, and Sweden). Hallin and Mancini did not distinguish between the 
media systems in the Nordic countries and Sápmi (following Strömbäck \& Aalberg, 2008). By comparing the features of the media system found in Sápmi with the democratic corporatist model articulated by Hallin and Mancini (2004) and, in particular, the components of state intervention, media autonomy, and professionalisation, we wish to explore similarities and differences (Herkman, 2009).

Hallin and Mancini's emphasis on media-politics relations has been criticised for neglecting interrelated variables, such as economic or cultural contexts. However, Hallin and Mancini (2010) acknowledged that some media systems can be different from Western media systems due to their different ways of organising political power. This could be the case with the indigenous Sámi people in Norway, Sweden, and Finland. Further, Strömbäck and Aalberg (2008) raised doubt about the supposed similarities among media systems in the Nordic countries. Some have questioned whether a Nordic model exists and if there is a shared understanding among journalists of what Nordic journalism is (Hovden et al., 2009).

Voltmer (2008) stated that models such as polarised pluralist, democratic corporatist, and the liberal may in fact exclude many countries, such as newly democratised Eastern European states that have different histories of development, including censorship and high state intervention. Political parties in Eastern European countries may play a less important role than, for example, "ethnicity, and individual leaders" (Voltmer, 2008: 27).

Still, the patterns of political and economic systems are structured. We see the importance of Hallin and Mancini's work on media systems precisely in the focused analysis of how exogenous mechanisms contribute to constructing local and regional media systems. However, when it comes to the understanding of endogenous mechanisms producing media systems from within minority communities and societies, much more research is needed.

Some question whether studying media systems within nation-states is appropriate in a time of accelerating globalisation. Jakubowicz (2010:9) argued that methodological nationalism is inappropriate, since "media systems are no longer exclusively related to single political systems". Nordic communication systems remain, to a significant degree, national in organisation and orientation (Hardy, 2010), but ownership of media is changing.

Studies of the Nordic bloc and the democratic corporatist model do not always seem to confirm Hallin and Mancini's results. According to Brüggemann and colleagues (2014), political parallelism, especially in the northern cluster, did not reach the high levels assumed by Hallin and Mancini (2004). Allern and Blach-Ørsten (2011: 93) found that "commercialization is not reducing political parallelism" in the Nordic bloc.

\section{Sámi and indigenous journalism}

To broaden the understanding of Sámi media history and the contemporary situation, we draw on Volker Hanusch and the five "dimensions of Indigenous Journalism: the empowerment role, language revitalisation, counter-narrative, reporting through a culturally appropriate framework, and the watchdog function of Indigenous Journalism" (Hanusch, 2013: 82). The role of indigenous media as a watchdog of power is twofold, since it guards the exercise of power by both indigenous and mainstream society's decision-makers (Sara, 2007). While the Western press has a strong historical commitment to political parties (Hallin \& Mancini, 2004, 2017) and an increasing tendency 
towards building large media corporations (Pickard, 2019), indigenous Sámi newspapers and the public service broadcasters have developed in response to a need to report news stories on issues relevant to the Sámi (Lehtola, 2001).

In Australia, alternative indigenous media have been seen to lead to greater inclusion of indigenous peoples in the mainstream media agenda (Meadows, 2001). Likewise, indigenous media in Australia was established to create positive counternarratives to challenge the often-negative media representations of indigenous Australians (Meadows, 2009), such as indigenous peoples being framed as "societal risks" by the nonindigenous print media (McCallum, 2013). Similarly, in Canadian mainstream media, the First Nations are expected to be either warriors, dancing, dead, drunk, or drumming in order to enter mainstream media (McCue, 2019).

Dahal and Aram (2013) found a link between democratisation of indigenous societies and indigenous journalistic practices in Nepal that foster policy change by publicly discussing "hidden issues" affecting indigenous communities. In Australia, indigenous participatory media tends to enshrine "diversity" by providing an arena for the multiplicity of indigenous voices (Dreher et al., 2016). The overwhelming power of the mainstream media pushed indigenous Australians to look for "access to their own media" and to create an alternative indigenous public sphere (Meadows, 2009: 118). Pietikäinen (2008: 180) found that one of the functions of indigenous journalism produced by YLE Sápmi is to "inform the public about important topical issues". Indigenous political journalism and Sámi news production affect public debate concerning Sámi issues, and hence influence mainstream policy-making concerning Sámi issues (Skogerbø et al., 2018).

\section{Methodology}

The media systems literature is concerned with a number of media system characteristics, such as high newspaper circulation, degree of pluralism, relationship to party press and commercial press, degree of autonomy, professionalisation of journalism, self-regulation, degree of state intervention, state protection for press freedom, press subsidies, and the role and function of public service broadcasting (Hallin \& Mancini, 2004).

Following Brüggemann and colleagues (2014), this study draws on the analysis of media systems as a method to investigate the media system in Sápmi. We explore the extent to which a Sámi media system can be said to exist and to be different from the corporatist democratic model developed by Hallin and Mancini (2004) to describe the Nordic media systems. We finally suggest dimensions and characteristics appropriate to describe a Sámi media system.

We used both historical and comparative methods to investigate the Sápmi media system. Synthesis is a well-established method in history with a number of "interpretive schools" and metanarratives existing side by side (Berkhofer, 2008: 81). According to Johannessen (2019), a synthesis builds on many detailed investigations to find patterns or causal and non-causal relations that have not previously been described. In this study, we researched existing studies to find patterns and relations that were similar to or different from those described in the media systems literature. Thus, we are indebted to eight scholars who have published works on the features of Sámi media landscapes, environments, infrastructure, public spheres, press, and so on (Hætta, 2003; Ijäs, 2011; Lehtola, 2001; Markelin, 2003; Markelin \& Husband, 2013; Rasmussen, 2017, 2018; 
Sara, 2007; Varsi, 1983). We first studied and systematised existing literature on Sámi media as well as previously unpublished documents, such as project descriptions and meeting notes (see $\S$ "A new media system" below) in order to propose a synthesis of Sámi media history. We needed this synthesis in order to systematically analyse the development of the media system's characteristics in Sápmi.

After constructing a history of the Sámi media system, we compared the emerging media system in Sápmi with the democratic corporatist model according to the media system characteristics. This comparison formed the basis for the conclusions we made regarding the possibility of Sámi self-determination over the media system.

\section{A history of the Sámi press}

In the synthesis of the history, we mainly followed the periodisation by Ijäs (2011) - a work heavily influenced by Varsi (1983) - in respect to newspapers. The development of broadcasting, however, has been driven by different mechanisms. Consequently, we propose a different periodisation for broadcasting.

\section{Newspapers in the assimilation period}

The history of the Sámi press starts with the establishment of the newspaper Muittalagje in 1873 (Ijäs, 2011). In his seminal book on Sámi press history, Ijäs described a period of numerous short-lived Sámi privately owned newspapers sharing goals such as informing the Sámi people, strengthening the Sámi language, and spreading Christianity. The first Sámi newspapers were established in a harsh political climate and did not last very long because of low circulation and lack of subsidies, advertisements, and government interest in supporting the Sámi language and culture (Ijäs, 2011). Sámi language and culture were neglected and even considered inferior to the majority language and culture and were thus opposed through assimilatory policies. This lack of interest, combined with hostility, lasted for the first hundred years of Sámi press history.

One of these short-lived newspapers was Muittalcegje, which stopped publishing after only two years. The editor emphasised "enlightenment" as a reason for publishing, and stated that it was crucial to inform Sámi people in their own language. Nuorttanaste followed in 1898 and is still being published - it is by far the oldest Sámi media. From the outset, Nuorttanaste was owned by Christian missionaries and still has a Christian mission statement. The newspaper has always been published in the North Sámi language, and it played a particularly important role in the Sámi public sphere during the harshest period of active "Norwegianisation policy in the beginning of the twentieth century" (Ijäs, 2011: 42). A third newspaper worth mentioning is Sagai Muittalcegje (published from 1904-1911 and 1921-1922); it had Sámi founders and owners and was published in the North Sámi language. It also had a clear political standpoint opposing Norwegianisation. During the first part of the twentieth century, many Sámi newspapers took political standpoints in the same way that Norwegian-language newspapers did at that time (Ijäs, 2011).

Already in this first period of Sámi press history, there was a schism regarding language use. The first Sámi newspapers were published in Sea Sámi areas in Norway using the Sámi language. In the southern Sámi areas, newspapers were published in 
Norwegian and Swedish. By 1930, only two Sámi newspapers remained: Nuorttanaste in Norway and Samefolkets Egen Tidning in Sweden, which managed to get a small grant from the state. In 1932, a group of Finnish researchers and intellectuals started to publish a monthly magazine, Sápmelaš, in the Sámi language and in support of the Sámi - it remained in publication until 2001 (Ijäs, 2011).

\section{Struggle for plurality, 1957-1990}

On the state level, a new and more positive policy toward the Sámi emerged slowly after World War II (e.g., Lehtola, 2015; Minde, 2005; Årseth, 2006). The social Darwinist view of the Sámi as "inferior" to majority populations was challenged, and a more human - but still patriarchal - policy prevailed. Nevertheless, the development of the Sámi press was slow. One of the few significant events was the establishment of a new newspaper, Ságat, which was launched in 1957 in Norway. At the beginning, Ságat was published in Sámi, but gradually Norwegian was used more frequently. By the 1970s, Norwegian was the dominant language in the paper (Ijäs, 2011).

As Ijäs (2011) discussed, especially during its first years, Ságat was cautious about criticising Norwegian authorities. This changed during the 1970s, with more radical editors-in-chief who had backgrounds in the new Sámi organisations. The 1970s was a turbulent time for the newspaper. A conservative wing of Sámi politics, supporting the labour party and the Christian Sámi mission, mobilised against the new radicalism among Sámi activists and managed to manoeuvre themselves into a majority stock position, taking over Ságat.

With some of the prominent members excluded from positions in Ságat, the radical wing established a new newspaper, Sámi Áigi, in 1979, to be published entirely in Sámi. Both conservative and radical Sámi made their voices heard through these two Sámi newspapers. At the same time, due to a language shift from Sámi to Norwegian particularly notable among Sámi in the coastal areas - Ságat could be seen as becoming the voice of the Sea Sámi, while Sámi Áigi was the voice of the inland Sámi-speaking Sámi (Ijäs, 2011). Both newspapers received production grants from the Norwegian government. Without grants, the newspapers would probably not have survived for long, since circulation as well as income from ads were low. The publication frequency was also low, varying from once every second week to twice a week.

\section{Reorganisation and professionalisation, 1990-2020}

As Ijäs notes (2011) after the establishment of the Sámi Parliament in 1989, Ságat changed its editorial line. Ságat became more independent of conservative Sámi politicians, starting to cover news more open-mindedly. The Sámi Parliament became an important arena for news, and the newspaper declared itself as "neutral" in Sámi politics.

On the other wing, Sámi Áigi went bankrupt in 1993, and two new Sámi language newspapers, Áššu and Min Áigi, were established. ${ }^{1}$ Similar to Ságat, Sámi Áigi was owned by Sámi organisations, municipalities, and individuals. In 1993, Norwegian newspapers came in as minority owners of the two new Sámi newspapers. In 2008, the two newspapers were merged into a new newspaper named Ávvir, with Norwegian owners in the majority ever since. At the same time, subsidies from the Norwegian government increased enough to ensure five days a week of publishing for both Ságat and Ávvir. This 
led to an increase in the number of journalists, a strengthening of the editorial room in general, and the establishment of local offices in new localities (Ijäs, 2011).

In Sweden and Finland, there were few changes during this period, but Samefolkets egen tidning in Sweden stopped publishing in 1958 before starting again (1961) under the name Samefolket. Samefolket was owned by Sámi organisations and published mostly in Swedish. In Finland, the Society for Promotion of Saami Culture, dominated by Finnish intellectuals, continued publishing Sápmelaš in Sámi until 2001 (Ijäs, 2011). Since 2012, the regional newspaper Lapin Kansa - subsidised by the government - has published news in Sámi in its ordinary outlets in print and on the Internet (YLE Sápmi, 2013).

\section{Sámi broadcasting history}

Sámi radio history started on Christmas Eve in 1936, when Christian services were transmitted directly from the church in Buolbmát/Polmak ${ }^{2}$ in Norway. For the first time, the Sámi language was heard on radio (Hætta, 2003). Since then, Sámi radio and television have been almost exclusively linked to national broadcasting corporations in Norway, Sweden, and Finland. The only notable exception is a local radio station, GLR, in Guovdageaidnu/Kautokeino, Norway.

\section{The initial period, 1946-1965}

After World War II, the Norwegian (1946), Finnish (1947), and Swedish (1953) national broadcaster corporations - NRK, YLE, and SR, respectively - established permanent Sámi programming. However, the Sámi journalists worked in the broadcasters' offices outside the Sámi area, staff for Sámi programming was limited to one person in each country, and Sámi programmes only transmitted 15-30 minutes a week (Hætta, 2003; Lehtola, 2001). Still, these programmes had a tremendous impact - stories tell of "whole villages" gathering in houses with radios to listen to the programmes (Hætta, 2003).

According to Lehtola (2001), nobody was actively advocating for an independent Sámi radio station before the 1960s. Both Hætta (2003) and Lehtola (2001) explained that Sámi representatives, and a number of non-Sámi friends, instead built relationships with national broadcaster representatives on regional and national levels, arguing that the Sámi needed both information and Christian services in their own language. They had some success. Still, the three decades after World War II were a period of slow progress in the history of Sámi broadcasting.

\section{Capacity building and failed mergers, 1965-1980}

In the 1960s, Sámi representatives and media leaders wanted to build up better broadcasting services for the Sámi. A working group under the Nordic broadcasters' Nordkalotten [The Cape of the North] conferences tried to unify forces and combine resources. In 1968, the working group suggested establishing a Sámi radio and television production centre in Kárášjohka/Karasjok, Norway. This project was put on hold because of technical issues, as Norway only had one landline for radio and was not willing to dedicate more time to Sámi radio programmes on this line (Hætta, 2003).

In 1974, the proposal was put on the agenda again. A working committee of regional national broadcaster leaders suggested the establishment of a Sámi production centre in 
Guovdageaidnu/Kautokeino, Norway, with local offices in the two other Nordic countries. The centre would have had 15 employees from the start, a number that would be increased to 40 in a short time (Hætta, 2003).

The plan was turned down by the Sámi conference the same year. With a majority of only one vote, the conference instead voted to place the centre in Giron/Kiruna in Sweden. Because of this change of location to outside Norway, NRK withdrew and instead decided to build an NRK Sámi radio office in Kárášjohka/Karasjok. During the 1970s, Swedish radio SR and Finnish radio YLE also moved their Sámi offices to a Sámi area - SR to Giron/Kiruna in Sweden and YLE to Anár/Inari in Finland - and developed their broadcasting capacity in Sámi (Hætta, 2003; Lehtola, 2001).

No analysis has been published to explain why the Sámi conference changed the location of the centre. A resolution from a meeting of Sámi radios' employees in 1976, however, indicated that the conference feared centralisation. The conference did not believe a centre would improve Sámi cooperation as promised (Hætta, 2003). The resolution indicates that participants might have thought it better to build up Sámi units within national broadcasters, rather than starting up something new and unknown.

From a media systems perspective, the failed attempt to establish a Sámi media centre and to coordinate Sámi journalists across borders was a crucial moment that merits more research. The efforts suggested the real possibility of developing a self-governed Sámi media system across borders. Instead, the fast-growing Sámi media came to be gradually more dominated by national broadcasters and developed according to interests defined within state systems and national borders.

\section{Consolidation and rapid development, 1980-2020}

During this most recent period, it has not been the strategy of the national broadcasters to merge the Sámi radio stations. Instead, the strategy has been to build up the broadcasting capacity of Sámi units in each country. Nevertheless, cooperation between the Sámi units of national broadcasters has continued by exchanging news and radio programmes and by assisting each other in producing radio programmes. The leaders of the Sámi units meet annually in a cooperation committee (Heatta, 2017; Lehtola, 2001).

However, the development of the Sámi broadcasters differed considerably between the Nordic countries during this period. Sámi broadcasting improved only slowly in Sweden and Finland, while the development of NRK's went into a phase of rapid development. Much of this was connected to personal interests on the leadership level. In 1989, for instance, a former leading labour politician, Einar Førde, became the head of NRK. Nils Johan Heatta was then the head of NRK Sámi radio - a position he held for 30 years. Heatta convinced Førde of the need for a serious commitment to Sámi broadcasting services, and NRK initiated a development plan for that purpose. The annual budget and the number of journalists and other employees increased, the radio channel got more airtime, and Sámi television production started up (Heatta, 2017; NRK Sápmi, 2017; Rasmussen, 2018).

During the 1980s and 1990s, the radio stations NRK Sápmi, YLE Sápmi, and SR Sameradion cooperated on small-scale projects. They exchanged programmes and established a common web-based newspaper in 1999 and a common news transmission in 2000. In 2001, a unique television service was launched as NRK, YLE, and the Swedish 
television broadcaster SVT joined forces to cooperate on daily television news in Sámi languages in Norway, Finland, and Sweden. The news programmes were published, with subtitles, 15 minutes per day, five days per week (Heatta, 2017; NRK Sápmi, 2017).

In recent years, the question of establishing an independent Sámi broadcaster has been discussed. A resolution from the annual meeting of The Sámi Journalist Association in 2004 encouraged Sámi politicians and media leaders to establish a Sámi broadcaster company. In 2018, the former head of NRK Sámi radio, Nils Johan Heatta (2018), then the leader of the Sámi Journalist Association, raised the question again in a media interview, advocating Sámi self-determination in the media sector and stating that all public broadcasting to the Sámi was governed by non-Sámi.

\section{A new media system}

During the 1990s, and especially after 2000, several innovations took place in Sámi society that indicated a development toward an independent and a more autonomous Sámi media system.

Sámi University College (since 2015, the Sámi University of Applied Science) started to teach journalism at the beginning of the $1990 \mathrm{~s}$ - first as a one-year introduction course on campus followed by two years at other Nordic journalism schools. Since 1999, the course has developed into a two-year candidate of journalism programme, a bachelor of journalism degree, and eventually into a master's programme of Sámi journalism from an indigenous perspective starting in 2015 (Rasmussen, 2017).

On the press organisation level, there were also some important developments in the 1990s. A Sámi publisher organisation, SALAS, was established in 1994. The daily Sámi newspapers Ságat and Ávvir are members of SALAS (Solbakk, 2006). A Sámi Journalist Association was established in 1998 and is, in itself, one element of an independent Sámi media system. From the outset, it worked on Sámi press ethics and started a Sámi code of ethics project. A follow-up was planned jointly with Sámi University College in the early 2000s, aimed at planning a Sámi press self-regulation scheme. According to the project's description, the self-regulation scheme would consist of a Sámi press union, codes of Sámi press ethics, and a complaint commission. However, the project was never carried out due to a lack of finances (Rasmussen's personal notes).

Since their establishments, the Sámi parliaments have started to finance media, subsidising the old Sámi media, as well as ten new Sámi media. Compared to the Sámi parliaments in Sweden and Finland, the Sámi Parliament of Norway grants by far the most funding (the budget is NOK 4.8 million in subsidies for a total of nine media in 2020). Most of these media are owned by Sámi organisations and companies and have a low publishing frequency (1-12 issues per year) (Rasmussen, 2018; Sámi Parliament of Norway, 2019).

\section{A Sámi model: Media system characteristics}

Hallin and Mancini (2010) have welcomed academics to bring insight into media systems beyond the Western world. Based on the literature of Sámi and other indigenous media, we contribute by reflecting on what an ideal type of Sámi media system model could look like. 
The existing media system in Sápmi is the result of the processes that have taken place due to the tensions between the indigenous and Western worlds. It is a combination of three different Sámi media or subsystems affected by the journalistic practices of the three Nordic countries Norway, Finland, and Sweden (Hallin \& Mancini, 2010). The state of the Sámi media system is sometimes contradictory. It can be said that state colonialism and intervention, as well as the political and economic systems of each Nordic country, have had a great impact on the development of the Sámi media system. As a minority media, the indigenous Sámi media have always depended on both external financing and the political climates of the states (Markelin, 2017), both of which have consequently impacted the ways in which the Sámi media system has developed.

Over the years, the role and function of the Sámi media have been envisaged by activists and organisations. More recently, the various Sámi parliaments have had some impact on the direction in which the Sámi media system has developed. The goals have typically been to produce a counterforce to mainstream media by creating indigenous counternarratives in Sámi languages, and to cover issues in culturally appropriate ways for the Sámi people (Hanusch, 2014). Building on Fanon and colleagues (2104), counternarratives should be understood as both those designed to counter the narratives about the Sámi among majority populations as well as those constructed to heal the psychological effects of colonialism among the Sámi-speaking population. The result has been envisaged to be a Sámi media system that could act as a watchdog while producing indigenous political journalism on Sámi matters (Skogerbø et al., 2018) that have been excluded from the mainstream media agenda (Pietikäinen, 2008). The Sámi media system was intended not only to provide reliable information for the Sámi (Hanusch, 2013) but also to contribute to building an alternative indigenous public sphere (Meadows, 2009) in order to discuss important matters for the Sámi and other indigenous peoples across the globe.

The Sámi parliaments have contributed to building a (small) alternative Sámi media system. However, the states and outside capital continue to control the development of Sámi media. In accordance with Hallin and Mancini (2010: 56), the Sámi media system differs from the Western media systems because the Sámi indigenous ethnicity facilitates alternative ways for the "organizing of political power" (following Voltmer, 2008).

\section{Industry, parallelism, professionalisation, and the state}

The Sámi media system has never experienced high levels of newspaper circulation (Ijäs, 2011). One reason is the low number of Sámi. In addition, this small population uses existing newspapers to a limited degree. Even when the Sámi press circulation was at its peak around the year 2000, we estimate that it would have to be placed in the very lower part of the list of newspaper sales per 1,000 adult population. The total sale of Sámi newspapers must have been less than 100 per 1,000 adult Sámi population (Hallin \& Mancini, 2004; Ijäs, 2011).

From a historical perspective, we observe the development of different kinds of political parallelism, different from the one that Hallin and Mancini (2004) described and analysed. Sámi newspapers have been established mainly to contradict or counter majority media and political systems in the three countries. In Sámi media, political pluralism only came to exist when two, and then three, Sámi newspapers competed for influence after 1979. In line with de Albuquerque (2013), we argue that the concept of 
political parallelism poorly fits media systems outside the Western world, because these societies often lack competitive political systems.

Historically, strong Sámi organisations and a press connected to the Sámi movement characterised the Sámi media system until 2000. In both Norway and Sweden, Sámi organisations were the driving force in establishing Sámi newspapers (Ijäs, 2011). This indicates that there are ways of organising political power based on ethnicity (Voltmer, 2008) and that indigeneity affects the ways in which the media systems beyond the Western world evolve over time. Since the 1990s, we have observed a shift from a Sámi press owned by Sámi organisations toward a Sámi press owned by Norwegian media. This could be classified as a move toward greater professionalisation of Sámi media, but it also signifies a loss of Sámi self-determination over the Sámi media system (Ijäs, 2011).

The establishment of Sámi journalism education during the 1990s and 2000s led to the professionalisation of Sámi media. The foundation of a press association at the same time further contributed to the advancement of professionalism. Still, the Sámi media system lacks institutionalised self-regulation based on proper Sámi codes of media ethics and a complaint commission. More research is needed to determine the ideal characteristics of such an institutionalised self-regulation of the Sámi media.

Strong state intervention in Sámi media has been the case throughout history. State intervention has been seen as necessary, since the Sámi society has not historically had control over Sámi economic resources and thus lacks the capacity to make large-scale investments.

\section{Conclusions}

The current media system in Sápmi has continued to develop as journalists and media have negotiated numerous dilemmas and tensions. On the one hand, we see Sámi media as having evolved from processes endogenous to Sámi communities. However, we have also seen the ever-present interaction, cooperation, and conflict with external actors such as missionaries, investors, and in particular, state institutions, as noted by Markelin (2003).

The state level has come to play an increasingly important role through state press subsidies and "national" public broadcasting services. This happened because Sámi activists and organisations won collective rights at both the state and international levels. Also, the majority populations in the Nordic countries have become more understanding of Sámi rights and culture in general, and Nordic public broadcasters embrace Sámi cultural expressions such as music, handicrafts, and arts.

The boom in Sámi media from the 1990s led to the establishment of a Sámi journalist association and journalism education. However, attempts to construct proper ethics for Sámi journalism failed, as have attempts to establish autonomous bodies to distribute production grants. Today, applications for production grants are handled by state-organised bodies, such as the Norwegian Media Authority. Nor has the boom in Sámi media succeeded in establishing Sámi public broadcasting covering all Sámi people across national borders. The state-financed public broadcasters are by far the biggest employers of Sámi journalists and producers of Sámi journalism. We have observed that fundamental processes governing Sámi media are subjected to regulations, procedures, and institutions constructed by state-centred processes. As Markelin and 
Husband (2013) have already demonstrated, the Sámi media landscape is shaped by four states with different political and economic frameworks, creating unique nationally defined environments. The same could be said about the emerging Sámi media systems. Over the last few decades, we have further seen Nordic media companies taking control over a substantial portion of the Sámi press. Thus, Sámi journalism and media depends to a large degree on non-Sámi journalists, organisations, companies, and state institutions.

The current media system in Sápmi could be called a hybrid model. To some extent, it brings to mind indigenous postcolonial political systems, as Sámi cultural awakening makes Sámi journalism and media more self-confident about language and culture. The majority of society is increasingly interested in the Sámi culture; at the same time, however, this interest contains elements of "settler colonialism", characterised by the ways colonial states establish their institutions in colonised areas. The majority of those working in these institutions are Sámi, and the leaders of the relevant media institutions are normally Sámi, but still, institutions are operating within institutional frameworks of the nation-states.

As Ijäs's (2012) research revealed, Norwegian media tend to show interest in Sámi politics only when the interests of the majority population are perceived to be threatened by Sámi interests, typically when conflicts arise regarding territories, land, and water resources. Research elsewhere has produced similar findings related to other indigenous peoples (Alia, 2012; Dahal \& Aram, 2013; Dreher et al., 2016; Krøvel 2017). In these cases, the media habitually supports state interests over indigenous interests. It is difficult to talk of a Sámi media system when control over financing and regulation is mostly outside the scope of Sámi self-determination. Analysing the history of Sámi journalism and press, we find that the Sámi media system lacks true autonomy. Developing such autonomy would undoubtedly deepen Sámi self-determination in general.

\section{Notes}

1. Two authors of this paper, Inker-Anni Sara and Torkel Rasmussen, worked for the latter newspaper.

2. City names are presented with their Sámi name first, then the national language.

\section{References}

Alia, V. (2012). The new media nation: Indigenous peoples and global communication (2nd ed.). New York: Berghahn Books.

Allern, S., \& Blach-Ørsten, M. (2011). The news media as a political institution. Journalism Studies, 12(1), 92-105. https://doi.org/10.1080/1461670X.2010.511958

Berkhofer, R. (2008). Fashioning history: Current practices and principles. New York: Palgrave Macmillan. https://doi.org/10.1057/9780230617209

Broderstad, E. G. (2010). The promises and challenges of indigenous self-determination: The Sami case. International Journal, 6(4), 893-907.

Brüggemann, M., Engesser, S., Buchel, F., Humprecht, E., \& Castro, L. (2014). Hallin and Mancini revisited: Four empirical types of Western media systems. Journal of Communication, 64(6), 1037-1065. https:// doi.org/10.1111/jcom.12127

Burrows, E. (2018). Indigenous media producers' perspectives on objectivity, balancing community responsibilities and journalistic obligations. Media, Culture \& Society, 40(8), 1117-1134. https://doi. org/10.1177/0163443718764807

Dahal, S., \& Aram, I. A. (2013). Empowering indigenous community through community radio: A case study from Nepal. The Qualitative Report, 18(82), 1-26. http://www.nova.edu/ssss/QR/QR18/dahal82.pdf

de Albuquerque, A. (2013). Media/politics connections: Beyond political parallelism. Media, Culture \& Society, 35(6), 742-758. https://doi.org/10.1177/0163443713491302 
Dreher, T., \& McCallum, \& Waller, L. (2016). Indigenous voices and mediatized policy-making in the digital age. Information, Communication \& Society, 19(1), 23-39. https://doi.org/10.1080/1369118X.2015.1093534

Fanon, F., Gibson, N. C., Damon, L., Cherki, A., \& Beneduce, R. (2014). Decolonizing madness: The psychiatric writings of Frantz Fanon. New York: Palgrave Macmillan.

Hallin, D. C., \& Mancini, P. (2004). Comparing media systems: Three models of media and politics. Cambridge: Cambridge University Press. https://doi.org/10.1017/CBO9780511790867

Hallin, D. C., \& Mancini, P. (2010). Comparing media systems: A response to critics. Media \& Jornalismo, 9(2), 53-67. http://fabricadesites.fcsh.unl.pt/polocicdigital/wp-content/uploads/sites/8/2017/04/17_4-artigo.pdf

Hallin, D. C., \& Mancini, P. (2012). Introduction. In D. C. Hallin, \& P. Mancini (Eds.), Comparing media systems beyond the Western world. Cambridge: Cambridge University Press. https://doi.org/10.1017/ CBO9781139005098

Hallin, D. C., \& Mancini, P. (2017). Ten years after Comparing Media Systems: What have we learned? Political Communication, 34, 155-171. https://doi.org/10.1080/10584609.2016.1233158

Hanusch, V. (2013). Charting a theoretical framework for examining Indigenous journalism culture. Media International Australia, 149(1), 82-91. https://doi.org/10.1177/1329878X1314900110

Hanusch, V. (2014). Dimensions of Indigenous journalism culture: Exploring Māori news-making in Aotearoa New Zealand. Journalism, 15(8), 951-967. https://doi.org/10.1177/1464884913495757

Hardy, J. (2010). Western media systems. London: Routledge. https://doi.org/10.4324/9780203869048

Heatta, N. J. (2017, March 24). NRK Sápmi history: The story of the development of an Indigenous media house [Lecture at Sámi University of Applied Sciences, Guovdageaidnu/ Kautokeino, Norway].

Heatta, N. J. (2018, December 6). Samer må ha selvbestemmelse over egne medier [Sámi need self-government over own media]. Altaposten. https:/www.altaposten.no/meninger/2018/12/06/--Samer-må-haselvbestemmelse-over-egne-medier-18009805.ece

Herkman, J. (2009). The structural transformation of the democratic corporatist model: The case of Finland. Javnost - The Public, 16(4), 73-90. https://doi.org/10.1080/13183222.2009.11009015

Hovden, J. F., Bjørnsen, G., Ottosen, R., Willig, I., \& Zilliacus-Tikkanen, H. (2009). The Nordic journalists of tomorrow: An exploration of first year journalism students in Denmark, Finland, Norway and Sweden. Nordicom Review, 30(1), 149-165. https://doi.org/10.1515/nor-2017-0144

Hætta, O. M. (2003). Dá lea Sámi Radio: NRK sámegiel sáddagat 1946-1980/NRKs samiske sendinger 1946-1980 [This is Sámi radio: On NRK's Sámi language programmes 1946-1980]. Karasjok, Norway: Davvi Girji.

Ijäs, A. J. (2011). Sámi preassa historjá: Muitalcegje rájes Ávvira rádjái [Sámi press history: From Muitalcegje to Ávvir]. Karasjok, Norway: Čálliid Lágádus.

Ijäs, A. J. (2012). Samer i to norske nyhetsmedier: En undersøkelse av saker med samisk hovedfokus $i$ Nordlys og Dagsrevyen i perioden 1970-2000 [The Sámi in two Norwegian news media: An investigation of cases with a Sámi focus in Nordlys and Dagsrevyen in the period 1970-2000]. Research series Dieđut, vol. 1. Kautokeino, Norway: Sámi University of Applied Sciences.

Jakubowicz, K. (2010). Introduction: Media systems research: An overview. In B. Dobek-Ostrowska, M. Glowacki, K. Jakubowicz, \& M. Sükösd (Eds.), Comparative media systems. European and global perspectives (pp. 1-21). Budapest: CEU Press.

Johannessen, F. E. (2019). Synteser i norsk historie: Norgeshistorie.no [Syntheses in Norwegian history: norwegianhistory.no]. Oslo: University of Oslo. https://www.norgeshistorie.no/studere-fortid/historie/2082Synteser-i-norsk-historie.html

Kulonen, U. M., Seurujärvi-Kari, I., \& Pulkkinen, R. (Eds.). (2005). The Saami - A cultural encyclopaedia. Suomalaisen Kirjallisuuden Seuran toimituksia 925 [Editions by the Finnish Literary Society 925]. Helsinki: The Finnish Literature Society.

Krøvel, R. (2017). Violence against indigenous journalists in Colombia and Latin America. In U. Carlson, \& R. Pöyhtäri (Eds.), The assault on journalism - Building knowledge to protect freedom of expression (pp. 191-203). Gothenburg: Nordicom, University of Gothenburg.

Lehtola, V.-P. (2001). Sámi jietna: Suoma Sámi radio 1947-1997 [The Sámi voice: Finnish Sámi Radio 1947-1997). Helsinki: Oy Yleisradio Ab.

Lehtola, V.-P. (2005). Saamelaisten Parlamentti: Suomen saamelaisvaltuuskunta 1973-1995 ja Saamelaiskäräjät 1996-2003 [Sámi Parliament: Finnish Sámi Delegation 1973-1995 and Sámi Parliament 1996-2003). The Sámi Parliament.

Lehtola, V.-P. (2015). Saamelaiset: Historia, yhteiskunta, taide [Sámi people: History, society and art]. Bookwell.

Markelin, L. (2003). Media, ethnicity and power: A comparative analysis of the Nordic Sami media environment in relation to state policies [Doctoral dissertation, University of Bradford, England].

Markelin, L. (2017). Indigenous voices in the global public sphere: Analysis of approaches to journalism within the WITBN network. Journal of Applied Journalism \& Media Studies, 6(3), 443-461. https:// doi.org/10.1386/ajms.6.3.443_1 
Markelin, L., \& Husband, C. (2013). Contemporary dynamics of Sámi Media in the Nordic States. Media International Australia, 149(1), 70-81. https://doi.org/10.1177/1329878X1314900109

McCallum, K. (2013). Distant and intimate conversations: Media and indigenous health policy in Australia. Critical Arts, 27(3), 332-351. https://doi.org/10.1080/02560046.2013.800667

McCallum, K., \& Waller, L. (2017). Indigenous media in Australia: Traditions, theories and contemporary practices. In J. Buderick, \& G. S. Han (Eds.), Minorities and the media in Australia (pp. 134-161). New York: Palgrave Macmillan.

McCue, D. (2019, November 15). A lecture on the Canadian context and stereotyping in Canadian media [Master's Programme on Sami Journalism from an Indigenous Perspective, Sami University of Applied Sciences, Norway].

Meadows, M. (2001). Voices in the wilderness: Images of aboriginal people in the Australian Media. Westport, Connecticut: Greenwood Press.

Meadows, M. (2009). Walking the talk: Reflections on Indigenous media audience research methods. Journal of Audience \& Reception Studies, 6(1), 118-136.

Minde, H. (2005). Assimilation of the Sami - Implementation and consequences. Gáldu Č́a -Journal of Indigenous Peoples Rights, 3. Resource Centre for the Rights of Indigenous Peoples. https://ir.lib.uwo.ca/aprci/196

Moe, H., \& Sjøvaag, H. (2008). The challenges of comparing media systems - An interview with Daniel C. Hallin. Journal of Global Mass Communication, 1(3/4), 132-141.

NRK Sápmi. (2017, November 6). NRK Sámi historjá [NRK Sápmi’s history]. NRK Sápmi. https://www.nrk. no/sapmi/om/7.-nrk-sami-historja-1.4201590

Pickard, V. (2019). Democracy without journalism? Confronting the misinformation society. Oxford: Oxford University Press.

Pietikäinen, S. (2008). Broadcasting indigenous voices: Sami minority media production. European Journal of Communication, 23(2), 173-191. https://doi.org/10.1177/0267323108089221

Rasmussen, T. (2017). Journalism studies for the indigenous Sámi - From preparatory courses to worldwide Indigenous master studies. WINHEC: International Journal of Indigenous Education Scholarship, 1, 40-56.

Rasmussen, T. (2018). Sámi media for children and youth: An underrepresented and problematic research field. Nordicom Information, 40(2), 88-102. https://www.nordicom.gu.se/en/node/40025

Rießler, M. (2015). Vom Matthäusevangelium zur Wikipedia: Medien für das bedrohte Kildinsaamische [From the gospel of Matthew to Wikipedia: Media for the endangered Kildin Saami]. In M.A. Niño, \& R. Kailuwait (Eds.), Medien für Minderheitensprachen: Mediensprachliche Überlegungen zur Entwicklung von Minderheitensprachen [Media for minority languages: Media language considerations for the development of minority languages] (pp. 127-158). Freiburg, Germany: Rombach.

Sámi Journalist Association. (2004). Resolution from an Annual Meeting March 20, 2004: Sámi radio ja TVfitnodaga ásaheapmi [On establishing of a Sámi radio and television company] [Unpublished document].

Sámi Parliament of Norway. (2019). Annual budget 2020 for the Sámi Parliament in Norway.

Sara, I.-A. (2007). Saamelaistoimittajien käsityksiä saamelaismedian tehtävistä [Sámi journalists'views of the role of the Sámi media]. Guovdageaidnu, Norway: The Nordic Sámi Institute, Sámi University College.

Skogerbø, E., Josefsen, E., \& Fjellström, A.-M. (2018). Indigenous political journalism in the Norwegian and Swedish public service broadcasters. Journalism Studies, 20(7), 991-1008. https://doi.org/10.108 0/1461670X.2018.1477550

Solbakk, J. T. (Ed.). (2006). The Sámi people - A handbook. Karasjok, Norway: Davvi Girji OS.

Strömbäck, J., \& Aalberg, T. (2008). Election news coverage in democratic corporatist countries: A comparative study of Sweden and Norway. Scandinavian Political Studies, 31(1), 91-106. https://doi. org/10.1111/j.1467-9477.2008.00197.x

Varsi, M.-O. (1983). Samisk ytrings- og pressefrihet under den norske støvel [Sami freedom of expression and the press, under the Norwegian boot]. Oslo: Norsk journalisthøgskole.

Voltmer, K. (2008). Comparing media systems in news democracies: East meets South meets West. Central European Journal of Communication, 1, 23-40.

YLE Sápmi. (2013, January 14). Lapin Kansas almmustuvvan sámegielat ságat ovtta jagi [Lapin Kansa published Sámi language news one year]. Yle. https://yle.fi/uutiset/osasto/sapmi/lapin_kansas_almmustuvvan_samegielat_sagat_ovtta_jagi/6621487

Årseth, B. L. (2006). Norsk samepolitikk 1945-1990: Målsetting, virkemidler og resultater [Norwegian Sámi policies 1945-1990: Objectives, instruments and results]. Drammen, Norway: Forlaget Vett \& Viten.

(C) 2021 Nordicom and respective authors. This is an Open Access work licensed under the terms of the Creative Commons Attribution-NonCommercial-NoDerivatives 4.0 International Public licence (CC BY-NC-ND 4.0). To view a copy of the licence, visit https://creativecommons.org/ licenses/by-nc-nd/4.0/ 